\title{
Aydın Bölgesinde Yetiştiriciliği Yapılan Bazı Mısır (Zea mays L.) Çeşitlerinin Tane ve Hasıl Verimlerinin Belirlenmesi*
}

\section{Determination of Grain and Forage Yield of Some Corn (Zea mays) Varieties Grown in Aydin Region}

\section{Orhan ALP}

\section{Yakup Onur KOCA ${ }^{1}$}

${ }^{1}$ Aydın Adnan Menderes Üniversitesi, Ziraat Fakültesi, Tarla Bitkileri Bölümü, Aydın

Sorumlu yazar: yokoca@adu.edu.tr

\section{ORCID (Yazar Sırasına Göre):}

D 0000-0002-2674-4046

(iD 0000-0002-0753-0077

Gönderilme Tarihi : 10 Şubat 2020

Kabul Tarihi ～: 9 Mart 2020

*Çalışma birinci yazarın yüksek lisans tezinden hazırlanmıştır.

\section{ÖZET}

$\mathrm{Bu}$ araştırma 2018 yılında Aydın ili’nde ana ürün tane mısır yetiştiriciliğinde kullanılan ve bazen silajlık olarak da değerlendirilebilen mısır çeşitlerinin tane verimi, bazı verim öğeleri (bin tane ağırlığı, koçanda tane sayısı ve koçan boyu), bazı tane kalite parametreleri (kül, lif, protein, nişasta ve yağ oranları) ve hasıl ot (koçan, yaprak ve sap) verimlerinin belirlenmesi amacıyla yürütülmüştür. Çalışma Adnan Menderes Üniversitesi Güney Kampüsü deneme alanında yapılmıştır. Deneme tesadüf blokları deneme desenine göre dört tekerrürlü olarak gerçekleştirilmiştir. Materyal olarak P1921, DKC6630, P1429, P1574, 71MAY69, İnove, 73MAY81，70MAY82, Gladius, P2088 çeşitleri kullanılmıştır. Çalışmanın sonucunda ortalama tane verimi $1503 \mathrm{~kg} \cdot \mathrm{da}^{-1}$ ve bazı verim öğelerinin ortalamaları bin tane ağırlığı 336,1 g, koçanda tane sayısı 595,5 adet ve koçan boyu 20,9 cm olarak ölçülmüştür. Tane kalite değerlerinin 
ortalamaları kül oranı \% 1,2, lif oranı \% 2,3, protein oranı $\% 8,2$, nişasta oranı $\% \quad 60,1$ ve yağ oranı \%3,1 olarak belirlenmiştir. Bunlara ek olarak yeşil ot verimi için ölçülen ortalama değerler ise yaprak ağırlığ1 191,4 g, sap ağırlığ1 278,7 g, koçan ağırlığı 402,1 g ve tüm bitki yeşil ağırlığı ise 875,7 g olarak ölçülmüştür.

Anahtar Kelimeler: misir (Zea mays), tane verimi, protein oranı, nişasta oran1, tek bitki yeşil ot verimi

\section{ABSTRACT}

The research was carried out to determination the highest grain yield, some yield components (a thousand grain weight, the number of grain in the cob and the length of the cob), some seed quality characteristics (ash, fiber, protein, starch and fat contents) and forage yields (cobs, stalks and leaves) of some corn varieties used as grain or sometimes as silage production in the province of Aydin during 2018. The study was conducted in Adnan Menderes University, South Campus in the research area. The trial was done randomized complete block design with four replications. The materials of the study were determined as P1921, DKC6630, P1429, P1574, 71MAY69, İnove, 73MAY81, 70MAY82, Gladius, P2088 corn varieties. As a result of the study, the average of grain yield was $15030 \mathrm{~kg} \cdot \mathrm{ha}^{-1}$ and the average of some yield components were measured as one thousand grain weight $336.1 \mathrm{~g}$, the number of grain in the cob 595.5, and the length of the cob 20.9 $\mathrm{cm}$. The averages of grain quality values were determined as ash content $1.2 \%$, fiber content $2.3 \%$, crude protein content $8.2 \%$, starch content $60.1 \%$ and oil content $3.1 \%$. In addition, mean values of green herb yield were measured as leaf weight $191.4 \mathrm{~g}$, stem weight $278.7 \mathrm{~g}$, cob weight $402.1 \mathrm{~g}$ and whole plant wet weight $875.7 \mathrm{~g}$.

Key Words: corn (Zea mays), grain yield, protein rate, starch rate, forage yield

\section{GIRİŞ}

Mısır, dünyada geniş üretim alanlarına sahip çok farklı çevre koşullarında yetişebilen bir bitkidir (Kün, 1985). Üretim alanı açısından buğday ve çeltikten sonra en fazla tarımı yapılan bir tahıldır. Üretim miktarı son yıllarda hızla artarak birinci sıraya yükselmiştir. Yaygın ekim ve kullanım alanlarına sahip mısır bitkisi gerek insan gerekse hayvan beslenmesinde kullanilan temel besin kaynakları arasında en üst sıralarda yer almaktadır (Başer, 1993). Buna ek olarak bir sanayi hammaddesi olarak da değerlendirilen mısır; nişasta bazlı şeker, bitkisel yağ, mısır unu, 
patlamış mısır gibi birçok sektörde kullanılan stratejik bir ürün olarak tanımlanmaktadır (K1rtok, 1998).

İnsan beslenmesinde tüketilen günlük kalorinin \%11'i mısır bitkisinden sağlanmaktadır. $\mathrm{Bu}$ oran gelişmiş Avrupa ülkelerde \%4'e düşerken, Meksika ve Orta Amerika gibi ülkelere \%27'ye kadar yükselmektedir (Anonim, 2018a). Genel olarak dünyada üretimi yapılan mısırın yaklaşık \%27'si insan beslenmesinde, yaklaş1k \%73'ü ise hayvan yemi olarak kullanılmaktadır. Gelişmekte olan ülkelerde mısırın kullanımı hayvan yemi olarak yaklaşık \%46 iken insan beslenmesinde yaklaşık \%54'dür. Gelişmiş ülkelerde ise bu oran hayvan beslenmesinde neredeyse \%90'larda iken, insan beslenmesinde yaklaşık \%10'dur. Misırın endüstride kullanımı diğer tahıllara göre artış göstermiş olup bu artışı devam ettirmektedir. Bunun sebebi; birim alandan yüksek verim alınması, kültürel işlemlerin kolay oluşu ve sürekli geliștirilme özelliğine sahip olmasıdır (Anonim, 2018b).

Mısır üretimi yıldan yıla artış göstermiştir. 2010 yılında 164 milyon hektar olan ekim alanı 2017 yılında 197 milyon hektara yükselmiştir. Üretim miktarı da ekim alanına paralel olarak 851 milyon tondan 1milyar 134 milyon tona yükselmiştir. Türkiye de mısır ekim alanları 2010 yılında 593 bin hektar iken 2017 y1lında 637 bin hektara yükselmiştir. Bununla beraber üretim miktarı da 4 milyon tondan yaklaşık 6 milyon tona yükselmiştir (Anonim, 2019). Bu denli önemli olan bitkinin özellikle uygun iklim koşulları ve ekolojiye sahip bölgelerde farklı üretim zamanlarında (birinci, ikinci hatta üçüncü ürün olarak), farklı kullanım amaçlarıyla (tane, silaj veya hasıl ot olarak) üretiminin artırılması büyük önem göstermektedir. Günümüzde ülkemizin özellikle Akdeniz ikliminin hakim olduğu bölgelerinde farklı yetiştirilme zamanları ile üretiminin hızla yükseltilebileceği konusu daha da önemsenmektedir. Bazı üretim planlamaları ve farklı kültürel uygulamalar ile hızlı bir şekilde üretimin yükselebileceği görülmektedir.

Uygun iklim koşulları ve ekolojiye sahip bölgelerde farklı üretim zamanlarında (birinci, ikinci hatta üçüncü ürün olarak), farklı kullanım amaçlarıyla (tane, silaj veya hasıl ot olarak) üretiminin artırılmasının en önemli unsuru çeşit seçimidir. Tipik bir C4 bitkisi olan mısırın (Özkan, 2001) koşullara uygun çeşitlerinin belirlenmesi ve kullanılması durumu göz ard1 edilirse beklenen üretim artışı bir yana büyük ürün kayıpları ve hatta hiç ürün alınamaması gibi olumsuzluklar yaşanabilir. Bu sebeple mısır çeşitlerinin olum dönemleri (FAO grupları ya da 
vejetasyon periyodu uzunlukları) birbirine yakın olarak bildirilse bile bitkinin yapısı, gelişim hızı, genel biyomas ağırlı̆ğ ve hatta kuruma hızı (tanenin nem atması) bile büyük önem taşımaktadır. Özellikle yıldan yıla yenilenen çeşitlerin bu tarz verilerinin güncellenmesi ve bunların üreticiye sunulması da benzer şekilde önem taşımaktadır. Bu sebeple Aydın İli ekolojik koşullarında ekonomik olarak yapılacak mısır yetiştiriciliği ve çeşit seçiminde yol gösterecek olan tanelik ve silajlık misir çeşitlerinin tane verimi, verim öğeleri ve bazı kalite parametrelerinin yanı sıra silaj verimine yönelik yeșil ot veriminin tespit etmek amaciyla yürütülmüştür.

\section{MATERYAL ve METOT}

Çalışmada Ege Bölgesinde mevcut olarak tarımı yapılan 10 adet mısır çeşidi (P1921, DKC6630, P1429, P1574, 71MAY69, İnove, 73MAY81, 70MAY82， Gladius， P2088) kullanılmıştır. Araştırma materyali tohum üretim ve dağıtım firmalarından temin edilmiştir. Kullanılan çeşitlerin geneli FAO 650-700 grubunda yer almakta olup verimözellikleri yüksek hastalıklara dayanıklı çeşitlerden oluşmaktadır. Tipik Akdeniz iklimi koşullarına (bölge koşullarına) uygun, yüksek tane verimi ve kalite özellikleri ile öne çıkan çeşitler olarak bilinmektedir. Bunlara ek olarak çeşitler nispi uzun boylu, yaprak ve koçan irilikleriyle de göz doldurmaktadır. Bölgemizde bazı yıllarda erken gelen bahar aylarında birinci ürün tanelik ya da üreticilerin ihtiyaçlarına göre birinci ya da ikinci ürün silajlık olarak bu çeşitler kullanılabilmektedir. Deneme; 2018 yılı ana ürün yetiştirme sezonunda Aydın Adnan Menderes Üniversitesi Ziraat Fakültesi Uygulama ve Araştırma Çiftliğindeki Tarla Bitkileri deneme alanında yürütülmüsştür. Çalışma; tesadüf blokları deneme desenine göre 4 tekerrürlü olarak kurulmuş olup mısır çeşitleri, 12 m uzunluğunda 4 ssradan oluşan parsellere $70 \mathrm{~cm}$ sıra arası ve $18 \mathrm{~cm}$ sıra üzeri sıklığında 05.04.2018 tarihinde pnömatik ekim makinası ile ekilmiş̧ir.

Denemenin yürütüldüğü tarlanın toprak analiz sonuçları Çizelge 1'de verilmiş̧ir.

Çizelge 1'de verilen analiz sonuçlarına göre deneme kurulan arazinin kumlu tınlı bir bünyesi olduğu, organik madde miktarı düşük ve reaksiyonu alkali karakterli bir yapıda olduğu söylenebilir. Ayrıca potasyum miktarının düşük, fosfor miktarının ise yüksek olduğu sonuçları elde edilmiştir.

Araştırmanın yürütüldüğü 2018 yllında eylül ayına kadarki dönemde Aydın ili’ne ait ortalama 
Çizelge 1. Deneme alanı toprak analiz sonuçları

\begin{tabular}{|c|c|c|c|c|c|c|}
\hline \multicolumn{3}{|c|}{ Toprak tekstürü(\%) } & \multirow{2}{*}{$\mathrm{ph}$} & \multirow{2}{*}{ Organik Madde (\%) } & \multirow{2}{*}{$\begin{array}{c}\mathrm{P} \\
(\mathrm{ppm})\end{array}$} & \multirow{2}{*}{$\begin{array}{c}\mathrm{K} \\
(\mathrm{ppm})\end{array}$} \\
\hline Kum & Mil & Kil & & & & \\
\hline 72 & 16.7 & 11.3 & 8.0 & 1.91 & 21 & 176 \\
\hline \multicolumn{3}{|c|}{ Kumlu tınl } & Yüksek & Düşük & Yüksek & Düşük \\
\hline
\end{tabular}

sıcaklık ve yağıș değerleri ile uzun yıllara ilişkin değerleri Çizelge 2.'de verilmiştir.
Taban gübresi olarak 15-15-15 kompoze gübresi ile dekara $10 \mathrm{~kg}$ saf azot, fosfor ve potasyum uygulaması yapılmıştır. Üst gübreleme işlemi

Çizelge 2. Araştırma yerinin 2017/2018 y1lı ve uzun yıllara ait ortalama sıcaklık ve yağış değerleri

\begin{tabular}{|c|c|c|c|c|}
\hline \multirow[b]{2}{*}{ Aylar } & \multicolumn{2}{|c|}{ Ortalama Sicaklık $\left({ }^{\circ} \mathrm{C}\right)$} & \multicolumn{2}{|c|}{ Toplam Yağış $\left(\mathrm{kg} \cdot \mathrm{m}^{-2}\right)$} \\
\hline & 2018 & $\begin{array}{l}\text { Uzun Yıllar } \\
\text { Ortalamas } 1\end{array}$ & 2018 & $\begin{array}{l}\text { Uzun Yillar } \\
\text { Ortalamas1 }\end{array}$ \\
\hline Ocak & 9,4 & 8,2 & 62,2 & 121,0 \\
\hline Şubat & 8,2 & 8,9 & 155,7 & 95,5 \\
\hline Mart & 12,1 & 11,7 & 92,6 & 71,1 \\
\hline Nisan & 15,7 & 15,7 & 39,8 & 45,5 \\
\hline Mayıs & 21,1 & 20,9 & 61,1 & 33,5 \\
\hline Haziran & 25,3 & 25,9 & 7,9 & 14,0 \\
\hline Temmuz & 28,8 & 28,4 & 9,3 & 3,5 \\
\hline Ağustos & 28,2 & 27,2 & 12,6 & 2,2 \\
\hline Eylül & 23,5 & 23,2 & 0,5 & 14,4 \\
\hline Ortalama/Toplam & 19,1 & 18,9 & 441,7 & 400,7 \\
\hline
\end{tabular}

Çizelge 2 incelendiğinde, denemenin yürütüldüğü 2018 misır üretim sezonunda (Nisan-Eylül) aylık ortalama sıcaklık değerlerinin uzun yıllara ait ortalama sıcaklık değerlerinden çok az farklılıklar gösterdiği söylenebilir. Buna karşın çalışmanın yürütüldüğü 2018 yılı eylül ayına kadar yağan toplam yağış miktarı uzun yıllar yağış miktarının üzerinde olduğu görülmüştür. bitkiler 6-8 yaprakl1 dönemde iken (18.05.2018) dekara $15 \mathrm{~kg}$ saf azot gelecek şekilde üre gübresi ile uygulanmıştır.

Hasat dönemi iki aşamalı olarak düşünülmüştür. Birinci aşamada çeşitler silaj olgunluğuna (hamur olum dönemi, tüm çeşitler $1 / 2$ ile $2 / 3$ ile süt çizgisi aralığında) geldiğinde (13.08.2018) parsellerin her iki yanından birer sira ve orta 
sıraların her iki ucundan da birer metrelik kısım kenar tesiri olarak çıkarılmış ve kalan kısım hasat alanı olarak belirlenmiştir. Hasat alanındaki sıraların baş tarafındaki birinci ve ikinci metreler arasında bulunan 1,4 $\mathrm{m}^{2}$ lik alandan 10 bitki ve son tarafindan onuncu ve on birinci metreler arasında bulunan 1,4 $\mathrm{m}^{2}$ lik alandan 10 bitki olmak üzere toplam 20 bitki kesilmiştir. Böylece parselin temsil edilme oranı daha yükseltilmiştir. Bu bitkiler hızlı bir şekilde parçalanarak tartılmıştır. Tüm bitki yeşil ağırlığı değerinin yanı sıra yaprak ağırlığı (koçan yaprakları da dahil), sap ağırlığı ve koçan ağırlığı değerleri de ölçülmüştür. İkinci hasat aşaması için parsellerde kalan bitkilerin tane hasat olgunluğuna gelmesi beklenmiştir. Silaj için hasat yapılan parsel bölümlerinden birer metre daha içeri girilerek (üçüncü ve dokuzuncu metre arası) $8,4 \mathrm{~m}^{2}$ lik alan da tane için hasat yapılmıştır. Tane nemi değerleri $\% 15$ ve altına düştüğünde tüm çeşitler elle (25.09.2018) koçanları kopartılarak hasat edilmiştir.

Parsellerden elde edilen materyal ambara taşınarak öncelikle tartılmış ve değerler dekara çevrilerek tane verimi değerlerine ulaşılmıştır (parsel alanı/dekar oranı, koçan/tane oranı ve tane nemi değerleri göz önünde bulundurularak). Buna ek olarak bin tane ağırlığı, koçan boyu ve koçanda tane sayısı değerleri de ölçülmüştür. Parsellerden elde edilen taneler kalite analizleri (protein oranı, kül oranı, nişasta oranı ve yă̆ oranı) için Adnan Menderes Üniversitesi Tarımsal Biyoteknoloji ve Gıda Güvenliği Merkezi (TARBIYYOMER) laboratuvarına getirilmiştir. Burada bulunan NIRS-FT (Bruker MPA) aleti ile ölçümler yapılmıştır. Ölçümler için aletin yaklaşı1k $9 \mathrm{~cm}$ çapında ve $2,8 \mathrm{~cm}$ derinliğindeki haznesine örnek konularak analizler gerçekleştirilmiştir (Gislum ve ark., 2004). Çalışmadan elde edilen tekerrürlü veriler varyans analizi (ANOVA) yöntemine göre değerlendirilmiştir. Ortalamalar arasındaki farklılıklar EKÖF çoklu karşılaştırma tesit ile belirlenmiştir (Acikgoz ve ark., 2004).

\section{BULGULAR ve TARTIŞMA}

Aydın ekolojik koşullarında bazı mısır çeşitlerinin değerlendirilmesine ait varyans analiz tablosu ve kareler ortalaması değerleri Çizelge 3'te verilmiştir. Varyans analizi sonuçları değerlendirildiğinde ölçülen tane verimi, verim öğeleri ve kalite özelliklerinin tamamında (tane verimi, bin tane ağırlığı, koçan boyu ve koçanda tane sayısı, protein oranı, kül oran1, nişasta oranı ve yağ oranı) çeşitler arasındaki farkın önemli $(\mathrm{P}<0,01)$ olduğu görülmektedir. 
Çizelge 3. Mısır çeşitlerine ait verilere ilişsin varyans analizi sonucunda elde edilen kareler ortalamaları

\begin{tabular}{|c|c|c|c|c|c|c|c|c|c|}
\hline \multirow[b]{2}{*}{ VK } & \multirow[b]{2}{*}{ TV } & \multirow[b]{2}{*}{ BTA } & \multirow[b]{2}{*}{$\mathrm{KB}$} & \multirow[b]{2}{*}{ KTS } & \multicolumn{5}{|c|}{ Tanede } \\
\hline & & & & & Kül & Lif & Pro & Niş & Yağ \\
\hline Çeşit & $127562,1 * *$ & $6379,8 * *$ & $14,9 * *$ & $36156,1 * *$ & $0,005 * *$ & $0,012 * *$ & $0,795 * *$ & $2,713 * *$ & $0,526^{* *}$ \\
\hline Hata & 2050,0 & 98,1 & 2,4 & 1131,2 & 0,001 & 0,003 & 0,032 & 0,127 & 0,006 \\
\hline Genel & 30886,0 & 1541,0 & 5,1 & 9203,7 & 0,002 & 0,005 & 0,206 & 0,715 & 0,130 \\
\hline \multicolumn{10}{|c|}{ *: 0.05 düzeyinde önemli, **: 0.01 düzeyinde önemli } \\
\hline
\end{tabular}

Buna ek olarak çalışma kapsamında ölçülen tüm bitki yeşil ağırlığı, koçan ağırlı̆̆1 ve sap ağırlığ1 değerlerinde çeşitler arasındaki fark önemli bulunmuştur. Yalnızca yaprak ağırlığı değerinde çeşitler arasındaki fark önemli bulunmamıştır. Çalışmadan elde edilen sonuçların bir kısmı (tane verimi, bazı verim öğeleri ve tane kalitesi ile ilgili olanlar) Çizelge 4'de verilmiştir. Ayrıca her çizelgenin içerisinde fark düzeyi önemli olan özelliğe ait hesaplanan en küçük önemli fark (EKÖF) değerleri de verilmiştir. Silaj verimi ile ilgili ölçülen yeşil ot değerleri (tüm bitki, koçan, yaprak ve sap olarak) grafik haline getirilerek Şekil 1'de verilmiştir.

Çalışma kapsamında yetiştirilen mısır çeşitleri arasında ölçülen tane verimi, bazı verim öğeleri

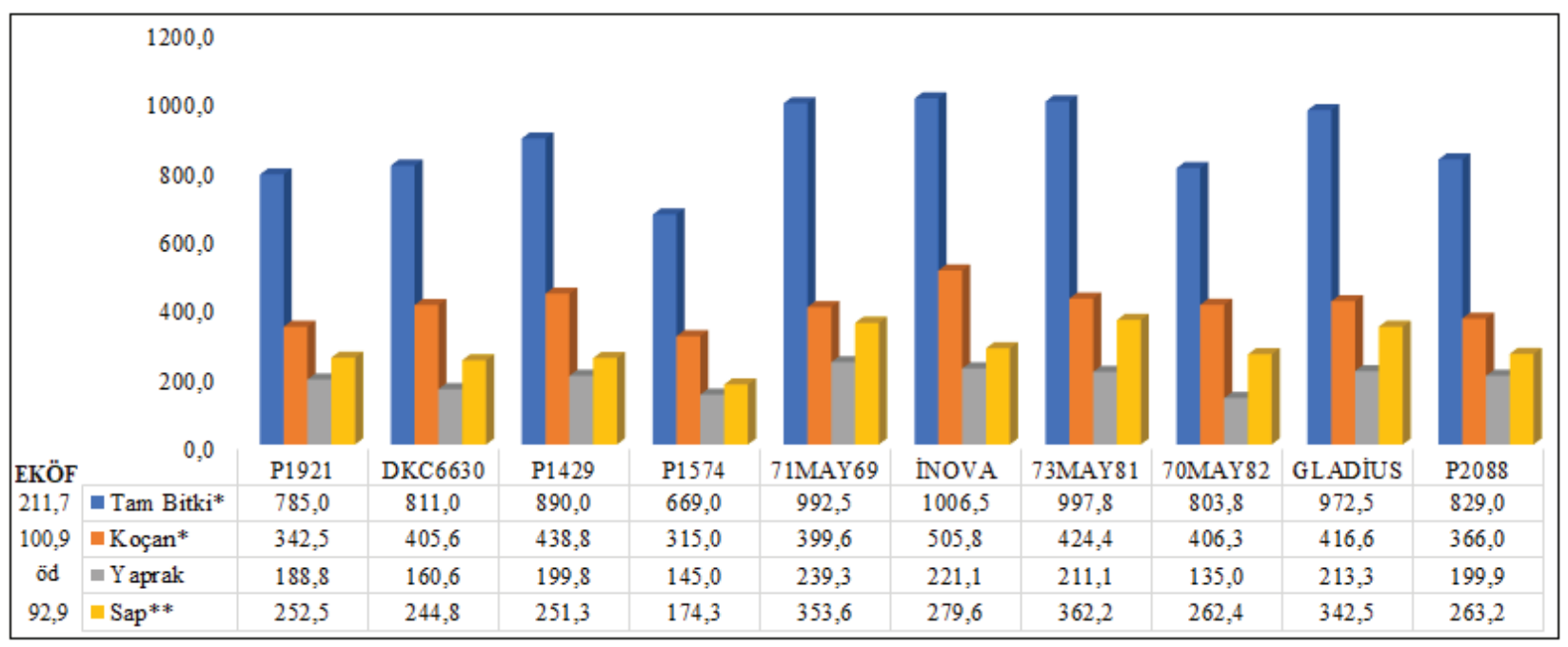

Şekil 1. Çalışmada yer alan silaj için biçilmiş mısır çeşitlerinin yeşil ağırlık $(\mathrm{g})$ ortalamaları $(\mathrm{P}<0,05)$ 
Çizelge 4. Farklı mısır çeşitlerine ait veriler

\begin{tabular}{|c|c|c|c|c|c|c|c|c|c|}
\hline \multirow{2}{*}{ Çeşitler } & \multirow{2}{*}{$\begin{array}{c}\text { TV } \\
\left(\mathrm{kg} \cdot \mathrm{da}^{-1}\right)\end{array}$} & \multirow{2}{*}{$\begin{array}{c}\text { BTA } \\
(\mathrm{g})\end{array}$} & \multirow{2}{*}{$\begin{array}{l}\mathrm{KB} \\
(\mathrm{cm})\end{array}$} & \multirow{2}{*}{$\begin{array}{l}\text { KTS } \\
\text { (Adet) }\end{array}$} & \multicolumn{5}{|c|}{ Tanede } \\
\hline & & & & & $\begin{array}{l}\text { Kül } \\
(\%)\end{array}$ & $\begin{array}{l}\text { Lif } \\
(\%)\end{array}$ & $\begin{array}{l}\text { Pro } \\
(\%)\end{array}$ & $\begin{array}{l}\mathrm{Niş} \\
(\%)\end{array}$ & $\begin{array}{l}\text { Yağ } \\
(\%)\end{array}$ \\
\hline P1921 & 1599,8 & 358,1 & 23,8 & 684,0 & 1,22 & 2,35 & 8,63 & 58,89 & 3,51 \\
\hline DKC6630 & 1688,7 & 377,9 & 23,1 & 676,0 & 1,23 & 2,38 & 8,51 & 59,05 & 3,35 \\
\hline P1429 & 1643,7 & 367,7 & 21,1 & 696,0 & 1,19 & 2,33 & 8,34 & 59,31 & 3,29 \\
\hline P1574 & 1648,0 & 369,1 & 19,5 & 572,0 & 1,19 & 2,33 & 7,90 & 59,97 & 2,81 \\
\hline 71MAY69 & 1369,4 & 306,4 & 18,3 & 426,5 & 1,19 & 2,29 & 7,75 & 60,52 & 2,78 \\
\hline İnove & 1332,5 & 298,5 & 19,6 & 592,0 & 1,21 & 2,32 & 7,79 & 60,51 & 2,58 \\
\hline 73MAY81 & 1177,3 & 262,6 & 19,4 & 520,0 & 1,16 & 2,24 & 8,09 & 60,69 & 3,20 \\
\hline 70MAY82 & 1432,7 & 320,6 & 19,3 & 476,0 & 1,14 & 2,27 & 7,46 & 61,49 & 2,58 \\
\hline Gladius & 1438,0 & 320,9 & 22,8 & 640,0 & 1,24 & 2,38 & 8,81 & 60,09 & 3,54 \\
\hline P2088 & 1703,4 & 379,4 & 22,1 & 672,0 & 1,25 & 2,42 & 8,52 & 60,62 & 3,16 \\
\hline Ortalama & 1503,3 & 336,1 & 20,9 & 595,5 & 1,20 & 2,33 & 8,18 & 60,11 & 3,08 \\
\hline $\begin{array}{l}\text { EKÖF } \\
(\mathrm{P}<0,05)\end{array}$ & 65,7 & 11,5 & 2,3 & 48,8 & 0,03 & 0,08 & 0,26 & 0,52 & 0,12 \\
\hline
\end{tabular}

(koçan boyu, salkımda tane sayısı ve bin tane ağırlığı) değerleri bakımından önemli farklar bulunmuştur. Çizelge 4 incelendiğinde tane verimi ortalamasının yaklaşık $1503 \mathrm{~kg} \cdot \mathrm{da}^{-1}$ olduğu görülmektedir. En yüksek tane verimi ortalamas1 $1703 \mathrm{~kg} \cdot \mathrm{da}^{-1}$ ile P2088 melez misır çeşidinde görülmüştür. Bu çeşidi DKC6630 (1689 kg. da $\left.{ }^{-1}\right)$ izlemiştir. Bunları sırasıyla P1574 (1648 kg.da ${ }^{-1}$ ) ve P1429 (1644 kg.da-1) çeşitleri takip etmiştir.

Sözü edilen çeşitler arasında tane verimi bakımından istatistiki fark gözlenmemiştir. Önemli bir verim öğesi olan bin tane ağırlığ1 değerleri incelendiğinde ortalamanın 336,1 g olduğu görülmektedir. En yüksek bin tane ağırlığı ortalamas1 379,4 g ile P2088 melez misır çeşidinde saptanmıştır. Bu çeşidi DKC6630 (377,9 g), P1574 (369,1 g) ve P1429 $(367,7$ g) çeşitleri takip etmiştir. Çeşitler istatistiki olarak aynı grupta yer almıştır. Bir diğer önemli verim öğesi olarak görülen koçanda tane sayısı değerlendirildiğinde genel ortalamanın 595,5 olduğu söylenebilir. En yüksek koçanda tane sayısı değeri 696,0 adet ile P1429 melez misır çeşidinden ölçülmüştür. Bu çeşidi P1921 (684 adet), DKC6630 (676 adet) ve P2088 (672 adet) çeşitleri takip etmiştir. Çeşitler arasında istatistiki olarak bir fark bulunamamıştır. Bazı kaynaklarda birincil verim öğeleri arasında sayılan koçan boyu değeri çalışmamızda 18,2 
cm ile 23,8 cm arasında değişmiş, ortalaması ise 20,9 cm olarak tespit edilmiştir. En yüksek koçan boyunun 23,8 cm ile P1921 misir genotipinden elde edildiği, onu 23,1 cm ile DKC6630, 22,8 cm ile Gladius ve 22,1 cm ile P2088 çeşitlerinin takip ettiği belirlenmiştir. Çeşitler istatistiki olarak aynı grupta yer almıştır.

Çalışmadan elde edilen tane verimi ve verim öğeleri genel olarak değerlendirildiğinde; elde edilen ortalama tane veriminin (1503 kg.da-1) bölge (Kıyı Ege) ekolojik ve iklim koşullarında (Akdeniz iklimi) yürütülen birçok çalışmada elde edilen veriler ile ya paralel ya da üzerinde olduğu görülmüştür (Kuşaksı ve Kaya, 2005; Cerit ve ark., 2007; Öktem ve Öktem, 2009; Çağlayan Dumral, 2015; Kuş, 2015). Özellikle maksimum dekara verimin 1703 kg olduğu göz önünde bulundurulursa çalışmanın yetiştiricilik açısından başarılı olduğu söylenebilir. Verim öğeleri açısından da yüksek verim veren çeşitlerin verim öğelerinin neredeyse tümünde (koçan boyu hariç) yüksek değerler elde edilmiştir. Önceden yapılan birçok çalışmalarda farklı morfolojik özellikler (bitki boyu, yaprak alanı, $\mathrm{m}^{2}$ de bitki sayısı, biyolojik verim, hasat indeksi, koçan yüksekliği, koçan boyu, koçan kalınlığı, koçanda tane sayısı, bin tane ağırlığ 1$)$ verim öğeleri olarak sıralanmıştır
(Xu, 1986; Jatimliansky ve ark., 1986; Debnath ve Sarkar, 1989; Angelov, 1994; Cesurer ve ark, 1999). Fakat genellikle sayılan verim öğelerinin arasında ters bir korelasyonun bulunduğu belirtilerek, özellikle mısır bitkisinde yüksek tane veriminin iyi dengelenmiş verim öğeleri ile oluşturulabileceği vurgulanmıştır (Arnon,1975; Gay ve Black 1984). Verim öğeleri içerisinde en önemlileri primer verim öğeleri olarak belirtilen birim alandaki tane miktarı (adet) ve ağırlı̆̆ $(\mathrm{g})$ değerleridir (Tollenear ve ark. 1992, Angelov 1994, Kara 2001). Bu çalışmada P2088, DKC6630, P1574 ve P1429 çeşitleri en yüksek tane verimini vermiştir. Bu çeşitler en yüksek bin tane ağırlığ 1 değerlerini de vermiştir. P1574 çeşidi koçanda tane sayısı bakımından, P1574 ve P1429 çeşitleri ise koçan boyu bakımından en yüksek değerleri gösterememiştir. Bunların yerine P1921 çeşidi hem koçan boyu hem de koçanda tane sayısı değerinde en yüksek verilerin elde edildiği grupta yer almıştır. Buna karşın çeşit tane verimi ortalamasında yaklaşık $1600 \mathrm{~kg} \cdot \mathrm{da}^{-1}$ ile istatistiki olarak en üstün bir altındaki grupta yer almıştır.

Çalışmadan ölçülen tanede kül, protein, nişasta, yăg ve lif oranları değerleri bakımından çeşitler arasında önemli farklar bulunmuştur. Tanede kül oranı değerleri incelendiğinde ortalamanın 
\%1,20 olduğu görülmektedir. Maksimum kül oranı değerini Gladius $(\% 1,25)$ çeşidinin verdiği söylenebilir. Bunu P2088 (\%1,24), DKC6630 $(\% 1,23)$ ve İnove $(\% 1,22)$ çeşitleri takip etmiştir. Çeşitler göreceli olarak farklı olsalar da istatistiki olarak değerlendirildiğinde aynı grupta yer almıştır. Tanede lif oranı değerleri incelendiğinde ise genel ortalamanın $\% 2,33$ olduğu görülmektedir. Maksimum lif oranı değeri, kül oranı değerinde de üst seviyelerde yer alan P2088 $(\% 2,42)$ çeşidinden elde edilmiştir. Bunu benzer değerler veren Gladius $(\% 2,38)$ ve DKC6630 $(\% 2,38)$ çeşitleri takip etmiştir. P1921 çeşidi \%2,35 değeri ile istatistiki olarak aynı grupta yer almıştır. Önemli bir tane kalite parametresi olan tanede protein oranı değerleri incelendiğinde ortalamanın $\% 8,18$ olduğu görülmektedir. Maksimum protein oranı değerini Gladius çeşidi \%8,81 değeri ile vermiştir. Bunu P1921 çeşidi $(\% 8,63)$ çeşidi takip etmiştir. Çeşitler arasında fark bulunamamıştır. Tanede nişasta oranı değerleri incelendiğinde genel ortalamanın \%60,11 olduğu görülmektedir. Maksimum nişasta oranı değeri, en düşük protein oranı $(\% 7,46)$ değerini veren 70 MAY82 $(\% 61,49)$ çeşidinden elde edilmiştir. Bunu benzer değerler veren Gladius $(\% 2,38)$ ve DKC6630 $(\% 2,38)$ çeşitleri takip etmiştir. P1921 çeşidi \%2,35 değeri ile istatistiki olarak aynı grupta yer almıştır. Tanede yağ oranı değerleri incelendiğinde ortalamanın $\% 3,08$ olduğu görülmektedir. Maksimum yağ oranı değerini Gladius $(\% 3,54)$ çeşidinin verdiği söylenebilir. Bunu P1921 çeşidi $(\% 3,51)$ takip etmiştir. Çeşitler istatistiki olarak değerlendirildiğinde aynı grupta yer almıştır.

Çalışma kapsamında yetiştirilen çeşitlerden elde edilen tane kalite özellikleri genel olarak değerlendirildiğinde önemli bir kalite parametresi olan protein oranı değerinin bölge iklim ve ekolojik koşullarında yapılan bazı çalışmalar ile paralel olduğu görülmüştür (Vartanl1 ve Emeklier, 2007; Koca ve ark., 2010). Yapılan birçok çalışmada tanede protein oranının önemine dikkat çekilmiş ve yükseltilmesi için çeşitli kültürel uygulamalar yapılabildiği vurgulanmıştır (Büyükerdem ve Akman, 2008; Çağlayan Dumral, 2015). Buna ek olarak tane verimi ile protein oranının arasında önemli olumsuz ilişki olduğu bilinmektedir (Terman vd. 1969). Gladius ve P1921 çeşitleri protein oranı bakımından en yüksek değerleri gösterdiği söylenebilir. Çeşitlerin yă̆ oranının yanı sıra lif oranı ve kül oranının da (kül oranında sadece Gladius) en yüksek değerleri göstermesi dikkat çekici bulunmuştur. Tane verim genel 
ortalamasının üzerinde ortalama veren P1921 $\left(1599,6 \mathrm{~kg} \cdot \mathrm{da}^{-1}\right)$ ve ortalamanın bir miktar altında değer veren Gladius (1438 kg.da ${ }^{-1}$ ) çeşitlerinin mısır tanesinin kullanım nedenlerine bağlı olarak (hayvan besleme, misır yağı, misır unu vb..) değerlendirilebileceği düşünülmektedir. Nişasta oranı açısından çeşitler arasında fark bulunmasa da elde edilen ortalamaların önceki yapılan bazı çalışmalarda mısır için verilen sınırın altında olduğu görülmüştür (Vartanlı ve Emeklier, 2007; İdikut ve Kara 2015). Nişasta oranı değerinde en yüksek ortalamayı veren 70MAY82 çeşidi protein oranı bakımından en düşük ortalamayı göstermiştir. Protein oranı değerinin nişasta oranı değerleri arasında önemli olumsuz ilişki olduğu bildiren çalışmalar bulunmaktadır (Karayel ve Bozoğlu 2017; Mut ve ark., 2017). Elde edilen bu sonuçlar paralel niteliktedir.

Çalışmadan elde edilen yeşil ağırlık verileri (tam bitki, koçan, yaprak ve sap) değerleri Şekil 1 de verilmiştir. Şekil 1 incelendiğinde çalışma kapsamında yetiştirilen çeşitlerden elde edilen tam bitki yeşil ot verimi, koçan ve sap verimi değerlerinde çeşitler arasındaki farkın önemli olduğu görülmektedir. Genel olarak tam bitki ağırlığ ortalamasının 875,7 g olduğu söylenebilir. Çalışmada İnove (1006,5 g) çeşidi maksimum değeri vermiştir. 73MAY81 (997,8 g), 71MAY69 (992,5 g) ve Gladius (972,5 g) çeşitleri bunu takip etmiştir. Koçan ağırlığ1 değerleri incelendiğinde genel ortalamanın 402,1 g olduğu söylenebilir. Maksimum koçan ağırlığ1 değeri tam bitki ağırlığına benzer şekilde İnove (505,8 g) çeşidi göstermiştir. Bunu P1429 (438,8 g) ve 73MAY81 $(424,4 \mathrm{~g})$ çeşitleri izlemiştir. Yaprak ağırlığı değerleri incelendiğinde genel ortalamanın 191,4 g olduğu görülmektedir. 71MAY69 (239,3 g) çeşidinin maksimum yaprak ağırlığı değerini verdiği söylenebilir. Bunu İnove (221,1 g), Gladius (213,3 g) ve 73MAY81 (211,1 g) çeşitleri izlemiştir. Sap ağırlığı değerleri incelendiğinde ise genel ortalamanın 278,6 g olduğu hesaplanabilir. Maksimum sap ağırlığı 73MAY81 (362,2 g) çeşidinden elde edilmiştir. Bunu 71MAY69 (353,6 g) ve Gladius $(342,5 \mathrm{~g})$ çeşitleri takip etmektedir.

Silajlık ürün yetiştiriciliğinde, bol yeşil aksam üretilmesi esastır. Silajlık mısır çeşidi seçiminde en çok üzerinde durulan önemli bir parametrenin yeşil ot verimi (yeşil ağırlık değerleri) olduğu bildirilmiştir (Çaçan ve İşikten, 2019). Yeşil ağırlık verileri değerlendirildiğinde tane verimi, verim öğeleri ve tane kalitesi konusunda fazlaca yüksek veriler göstermeyen İnove, 73MAY81, 71MAY69 ve Gladius çeşitlerinin öne çıktığ1 söylenebilir. 
Mısır çeşitlerinden elde ettiğimiz yaş ağırlık (yeşil ot) verileri, bölge ekolojik koşullarında yürütülen bazı çalışmalardan elde edilen veriler ile paralellik göstermektedir (Budak ve ark., 2005; Koca, 2009). Çalışmamızda silaj kalite parametrelerinin ölçülmemesine rağmen koçan oranının yüksek olması olumlu olarak nitelendirilebilir. Çünkü mısırda yeşil aksam veriminin \%50'si ve besleme değerinin \%70'i koçanlardan elde edilmektedir (Açıkgöz, 1991). Buna ek olarak koçan oranının yüksek oluşu silajda protein oranı ile de olumlu ve önemli ilişkili bulunmuştur (Güneş, 2017). Özellikle tam bitki ağırlığının yüksek olması ve bunun neredeyse yarısını koçan ağırlığının oluşturması İnove çeşidini ümitvar olarak nitelendirmemize sebep olmaktadır. 73MAY81 çeşidinin yüksek tam bitki ağırlığı ve nispi yüksek koçan ağırlığının dikkat çekmesine rağmen yüksek sap ağırlığının olumsuz özelliği olarak nitelendirilebilir. Bunların dışında P1429 çeşidi yüksek tane verimi ve yüksek sayılabilecek bin tane ağırlığının yanı sıra yüksek koçan ağırlığıyla da dikkat çekmektedir. Fakat çeşit tam bitki ağırlığı değerinde geri kalmıştır. Çeşit yeşil ot veriminden taviz verilerek ot kalitesinin göz önünde bulundurulduğu durumlarda tercih edilebilir. Mısır çeşitlerinin değişik olum gruplarına sahip olması ile bölgelerin ve ekolojileri ve ürün yetiştirme sürelerinin değişken olması çeşit performanslarını doğrudan etkileyebilmektedir. Doğru çeşitlerin doğru ekolojilerde yetiştirilmesi verimlilik açısından çok büyük önem taşımaktadır (Küçük, 2011).

\section{SONUÇ ve ÖNERILER}

Aydın İli ekolojik koşullarında yetiştiriciliği yapılabilecek mısır çeşit seçiminde yol gösterebilmesi için tane verimi, bazı verim öğeleri ve tane kalitesi unsurlarının yanı sıra silaj amaçlı yeşil ot verimi (tam bitki ağırlığı) ve koçan, yaprak ve sap ağırlığı değerlerini tespiti konulu çalışmamızda aşağıdaki maddeler halinde verilen sonuçlara ulaşılmıştır.

- Tane verimi sonuçları açısından değerlendirme yapıldığında, Çeşitler incelendiğinde en yüksek tane verimi ortalamaları P2088 (1703 kg/da), DKC6630 (1689 kg/da), P1429 (1644 kg/da) ve P1921 (1600 kg/da) çeşitlerinden elde edilmiştir.

- Verim öğeleri bakımından (bin tane ağırlığı, koçan boyu ve koçanda tane sayısı) değerlendirildiğinde tane verimi bakımından öne çıkan çeşitlerin (P2088, DKC6630, P1429 ve P1921) verim öğeleri bakımından da yüksek değerler gösterdiği söylenebilir.

- Tane kalitesi (protein, nişasta, yağ, kül, liforanı) 
özellikleri genel olarak incelendiğinde, Gladius çeşidinin nişasta oranı dışında tüm özelliklerde en yüksek değerleri verdiği görülmüştür. Bunu P1921 çeşidi nişasta ve kül oranı dışındaki tüm değerlerin yüksek olmasıyla takip etmiştir. Her iki çeşit tane kalitesinin en önemli parametresi olan protein oranı ile ilgili en yüksek değerleri vermiştir.

- $\quad$ Silaj amaçlı yeşil ağırlık verileri değerlendirildiğinde tane verimi, verim öğeleri ve tane kalitesi konusunda fazlaca yüksek veriler göstermeyen İnove, 73MAY81, 71MAY69 ve Gladius çeşitlerinin öne çıtı̆̆g söylenebilir. Özellikle İnove çeşidinin koçan ağırlığının yüksek olması dikkat çekici bulunmuştur. Çeşidin hem yüksek ot veriminin olması hem de bunun yaklaşık \%50 lik kısmının koçandan oluşması onu öne çıkarmıştır.

Sonuç olarak bu çalışma bir yıllık verileri kapsamaktadır. $\mathrm{Bu}$ nedenle daha güvenilir sonuçlar elde etmek için çalışmaların birkaç yıl daha sürdürülmesi uygun olacaktır.

\section{KAYNAKLAR}

Acikgoz, N., E. Ilker and A. Gokcol. 2004. Assessment of Biological Research on the Computer. ISBN: 973-483-607-8 Ege University Seed Technology Center, Publication No: 2 Bornova-Izmir, Turkey (in Turkish).

Açıkgöz, E., 1991. Yem bitkileri. Uludağ Üniversitesi Ziraat Fakültesi. Bursa.

Angelov, K. 1994. Correlations Between Grain Yield and Ear Characteristics in Maize Hybrids. Field Crop Abstr. Vol. 47: 133.

Anonim, 2018a. 80. Hesap Dönemi Faaliyet Raporu 2017. Toprak Mahsulleri Ofisi Y1llığ1. http://www.tmo.gov.tr/Upload/ Document/maliisler/2017faaliyetraporu. pdf

Anonim, 2018b. Tarımsal Ekonomi ve Politika Geliştirme Enstitüsü (TEPGE) Durum Tahmin Misır 2018 - 2019 raporu. https:// arastirma.tarimorman.gov.tr/tepge/ Belgeler/PDF\%20Durum-Tahmin\%20 $\mathrm{Ra} \quad$ porlar\%C4\%B1/2018-2019\%20 Durum\%20 Tahmin\%20 Raporlar/ M\%C4\%B1s\%C4B1r\%20Durum $\quad \% 20$ Tahmin\%20Raporu\%202017-2018-308. pdf

Anonim, 2019. 2019-2023 Stratejik Planı. 
Toprak Mahsulleri Ofisi Genel Müdürlüğü.

http://www.tmo.gov.tr/Upload/Document/ stratejikplan.pdf

Arnon, I. 1975. Mineral Nutrion of Maize. International Potash Institue. Bern/ Switzerland.

Başer, İ., 1993. Mısırda Verim ve Kaliteye Etkili Başlıca Karakterler ve Bunların Kalıtımı Üzerine Araştırmalar. T.Ü. Fen Bilimleri Enstitüsü, Doktora Tezi.

Budak B., Ö. Alan., H. Akdemr., 2005. Küçük

Menderes Koşullarında Bazı Melez Mısır

(Zea mays L.) Çeşitlerinin Hasıl Verimi

Üzerine Bir Araştırma. VI. Tarla Bitkileri

Kongre kitab1. 2: 1017-1020.

Büyükerdem, N.İ., Akman, Z., 2008. Effects of Different Zinc Containing Fertilizers Aplications on Ear Yield and Some Agronomic and Quality Characters of Sweet Corn. Journal of Plantand Evironmental Sciences 1,21- 27.

Cerit, İ., Turkay M.A., Sarıhan H., Korucu T., Say S.M., Ülger A.C., Kirişçi V., Şen H.M., 2007. İkinci Ürün Mısır Yetiştiriciliğginde Farklı Toprak İleme Yöntemlerinin Tane Verimi ve Bazı Toprak Özelliklerine Etkisinin Belirlenmesi. VII. Tarla Bitkileri Kongre kitab1 I: 113-116.
Cesurer, L., Akkaya, A., Çiçek, A., Yürürdurmaz, C., ve Demirbağ, V., 1999. İkinci Ürün Bazı Hibrid Mısır Çeşitlerinde Verim ve Verim Unsurları Arasındaki İlişkilerin Belirlenmesi. Orta Anadolu'da Hububat Tarımının Sorunları ve Çözüm Yolları Sempozyumu, Posterler: Hububat Islahı ve Çeşitler, 8-11 Haziran 1999, Konya, 640-644.

Çaçan E., İşikten S., 2019. Bingöl İli Ekolojik Koşullarında Bazı Silajlık Mısır Çeşitleri İçin Uygun Ekim Zamanının Belirlenmesi. Türkiye Tarımsal Araştırmalar Dergisi, 6(1): 39-49.

Çağlayan Dumral N.H., 2015. Farklı Çinko Dozlarının Misir (Zea mays L.) Çeşitlerinde Verim ve Tane Kalitesi Üzerine Etkisi. Adnan Menderes Üniversitesi Fen Bilimleri Enstitüsü Tarla Bitkileri Anabilim Dalı Yüksek Lisans Tezi, $65 \mathrm{~S}$.

Debnath, S. C. ve Sarkar, K. R. 1989. Quantitative Genetic Analysis of Grain Yield Some Other Agronomic Traits in Maize. Pakistan Journal of Scientific and Industrial Research, 32 (4); 253 - 256.

Gay, J. P. ve Blac, D. 1984. Control of The Components of Grain Yield. Physiologie 
Dumais. Collaque Organise for I'INRA

LE CNRS ET I'ACPM. Rayon, 15 - 17 march 1983, $181-192$.

Gislum R., Micklander E and Nielsen JP., 2004.

Quantification of nitrogen concentration in perennial ryegrass and red fescue using near-infrared reflectance spectroscopy (NIRS) and chemometrics. Field Crops Research, 88: 269- 277.

Güneş A., 2017. Bazı Silajlık Misır (Zea mays L.) Çeşitlerinin Silajlık Verim ve Kalite Özelliklerinin Belirlenmesi. Ordu Üniversitesi Fen Bilimleri Enstitüsü, Yükseklisans Tezi. 57 S.

İdikut, L., Kara, S.N. 2013. Tane Ürün için yetiştirilen ikinci ürün mısır çeşitlerinin bazı verim öğeleri ile tane nişasta oranlarının belirlenmesi. K.S.Ü. Doğa Bilim Dergisi. 16(1): 8-15.

Jatimliansky, J. R., Urrula, M. I. and Arturi, M. J. 1986. Relationships Between Photosynthesis, Canopy Traits and Yield in Flint Type Maize. Maize Genetics Cooperation Newsletter, $62-73$.

Kara, M. 2001. Bir Melez Misir Populasyonunda Verim ve Verim Unsurları Arasındaki İlişkilerin Korelasyon ve Path Analizi Yoluyla Değerlendirilmesi. A.Ü. Ziraat
Fakültesi Yayınları, Tarım Bilimleri Dergisi, 7, (4), 1-4, Ankara.

Karayel R., Bozoğlu H., 2017. Bezelye (Pisum sativum L.) Genotiplerinin Bazı Fizikokimyasal Özellikleri Arasındaki İlişkiler. Tarla Bitkileri Merkez Araştırma Enstitüsü Dergisi 2017, 26 (Özel Say1): 92-98.

Kirtok, Y. 1998. Misır Üretim ve Kullanımı. Kocaoluk Basın ve Yayınevi, Sayfa 445, İstanbul.

Koca Y.O., 2009. Aydın Bölgesinde Birinci ve İkinci Ürün Misırda (Zea mays) Verim, Verim Öğeleri, Fizyolojik ve Diğer Bazı Özellikler Arasındaki Farklılıklar. Adnan Menderes Üniversitesi Fen Bilimleri Enstitüsü Doktora Tezi. $80 \mathrm{~S}$.

Koca Y.O., Turgut İ., Erekul O., 2010. Tane Üretimi İçin Yetiştirilen Mısırın Birinci ve İkinci Üründeki Performanslarının Belirlenmesi. Ege Üniv. Ziraat Fak. Derg., 47 (2): 181-190.

Kuş H.O., 2015. Atdişi Misırda (Zea mays L. Indentata Sturt.) Yavaş Salımlı Azotlu Gübrenin Tane Verimi ve Verim Öğelerine Etkileri. Çukurova Üniversitesi Fen Bilimleri Enstitüsü Tarla Bitkileri Anabilim Dalı, Yüksek Lisans Tezi. 71 S. 
Kuşaksız T., Kaya Ç.., 2005. Manisa Koşullarında

Yetiştirilen Mısır Çeşitlerinin (Zea mays

L) Hasıl Verimleri Üzerine Bir Araştırma.

VI. Tarla Bitkileri Kongresi kitab1, II: 1021-1026.

Küçük B., 2011. Bazı Silajlık Mısır Çeşitlerinde

Morfolojik Özelliklerin ve Yem

Verimlerinin Belirlenmesi. Ankara

Üniversitesi Fen Bilimleri Enstitüsü, Yükseklisans Tezi. 65 S.

Kün, E. 1985. Sıcak İklim Tahılları. A.Ü.Z.F. Yayınları No: 680, A.Ü. Basımevi. Ankara. Mut, Z., Bayramoğlu, H.O., Özcan, H. 2007. Bazı ekmeklik buğday (Triticum aestivum L.) genotiplerinin verim ve başlıca kalite özelliklerinin belirlenmesi. OMÜ Ziraat Fakültesi Dergisi, 22(2): 193-200.

Öktem, A., Öktem, A.G., 2009. Bazı Atdişi Hibrit Misır (Zea mays indentata L.) Genotiplerinin Harran Ovası Koşullarında Performanslarının Belirlenmesi. Harran Üniversitesi, Ziraat Fakültesi Dergisi, 13(2):49-58.

Özkan, A., 2001. GAP Bölgesinde İkinci Ürün Olarak Yetiştirilen Farklı Misır Çeşitlerinin Hasıl ve Tane Verimleri Üzerinde Araştırmalar. Ege Üniversitesi Fen Bilimleri Enstitüsü. Yüksek Lisans
Tezi.

Terman, G.L., Ramig, R.E., Dreier, A.F., Olsan, R.A.1969. Yieldprotein relationships in wheat grain, as affected by nitrogenand water. Agron. J., 61 (5), 755-759.

Tollenear, M., Dwyer, L. M. and Stewart, D. W. 1992. Ear and Kernel Formation in Maize Hybrids Respresting Three Decades of Grain Yield. Improvement in Ontorio. Crop Science, 32: (2), $432-438$.

Vartanl1, S., Emeklier H.Y., 2007. Ankara Koşullarında Hibrit Misır Çeşitlerinin Verim ve Kalite Özelliklerinin Belirlenmesi. VII. Tarla Bitkileri Kongresi, Erzurum. Cilt I, S: 3742.

Xu, Z. B. 1986. Influence Major Characters of Maize on the Productivity of Indivudial Plants. Ningxia Agricaltural Science and Technology, 5: 26-27. 